\title{
PENGUKURAN GEOLISTRIK UNTUK INVESTIGASI LONGSOR DI AREA BANDUNG UTARA
}

\author{
BAMBANG WIJATMOKO ${ }^{\ddagger}$, KUSNAHADI SUSANTO, IMRAN HILMAN MOHAMMAD, DINI FITRIANI \\ Program Studi Geofisika, \\ Fakultas Matematika dan Ilmu Pengetahuan Alam \\ Universitas Padjadjaran
}

\begin{abstract}
Abstrak. Makalah ini mendiskusikan hasil dari penyelidikan keruntuhan tanah (ground failures) di sekitar cekungan Bandung menggunakan metode geolistrik. Penelitian dilakukan untuk mendeterminasi jenis ground failures dan bagaimana ciri menjelang keruntuhannya. Pada umumnya ground failures di sekitar cekungan Bandung disebabkan oleh curah hujan yang tinggi yang menyebabkan timbulnya penambahan volum air dalam tanah, sehingga mengurangi kuat ikatan molekul tanah. Ground failures terjadi dalam dua bentuk: keruntuhan bidang gelincir yang disebut tanah longsor dan keruntuhan vertikal/tebing. Penyelidikan keruntuhan tanah difokuskan pada dua lokasi di Bandung utara yaitu Legok hayam dan Cimenyan, dimana untuk daerah Legok Hayam longsor telah terjadi sementara daerah Cimenyan belum terjadi longsor namun memiliki tingkat kerawanan yang cukup tinggi. Hasil penyelidikan di kedua daerah dibandingkan untuk mengetahui kondisi struktur resistivitas bawah permukaan daerah pra dan pasca longsor di Bandung utara.
\end{abstract}

Kata kunci : Ground failures, tanah longsor, metode geolistrik

\begin{abstract}
Investigation of ground failures using DC Resistivity methods to determine the typical failures and its characteristics was conducted around Bandung basin. Ground failures around Bandung Basin are usually caused by very heavy rainfall and contributing to water filling in ground pores, which will decrease soil bond The ground failures could arise in the form of shifting ground called landslides and vertical collapse. Investigations of failures are focused on two areas in north Bandung, Legok Hayam and Cimenyan. The investigations were conducted to determine the characteristics of resistivities structure of pre and post landslide events in north Bandung area.
\end{abstract}

Keywords : Ground failures, landslides, DC Resistivity

\section{Pendahuluan}

Gerakan tanah pada kasus tanah longsor merupakan salah satu dari bencana geologi yang sering terjadi pada lereng dengan hambat geser antara tanah dan batuan lebih kecil daripada massa tanah atau batuan penyusun lereng. Penyebab tanah longsor dapat berlangsung secara alami, namun kebanyakan terjadi akibat aktivitas manusia seperti penebangan hutan, pemanfaatan air tanah yang berlebihan, dan pertanian padi atau palawija, terutama pada lereng yang curam. Gaya utama penyebab longsor adalah gaya gravitasi yang dipengaruhi secara signifikan oleh beberapa faktor antara lain laju penyerapan air oleh tanah lereng, kemiringan lereng, struktur geologi sekitar lereng dan aktivitas seismik sekitar area lereng. Selain itu aliran massa material dan keruntuhan lereng juga merupakan faktor penting pada terjadinya longsor, sehingga tanah longsor dapat diklasifikasikan sebagai berikut: jatuhan/falls (jatuhnya fraksi atau bagian tanah atau batuan), gelinciran/slides (timbulnya peristiwa gerakan material di atas bidang gelincirnya), dan aliran/ flows (aliran material dengan viskositas tinggi). Berdasarkan kondisi geologi, geomorfologi, hidrologi dan vegetasi sekitar area lereng, bencana tanah longsor dapat terjadi dengan kasus-kasus sebagai berikut: (1). Terjadinya rekahan di sekitar lereng parallel terhadap arah tebing, (2). Timbulnya cuaca ekstrim seperti curah hujan yang sangat tinggi, dan (3). Jatuhan dari bagian tebing yang rapuh.(Ludman,1982)

* email : bwmoko@geophys.unpad.ac.id 
Struktur tanah di Jawa Barat yang pada umumnya merupakan hasil letusan gunung api, membuat karakteristik penyebab di Jawa Barat menjadi unik. Hasil letusan gunung api yang sebagian besar didominasi oleh lempung dan sedikit pasir mengakibatkan tanah mengalami pelapukan dan pemanasan serta pengeringan di musim panas. Hal ini berakibat timbulnya rongga udara/pori dan rekahan di atas batuan kedap air yang pada musim penghujan akan terisi oleh resapan air. Dengan demikian potensi longsor terbesar timbul akibat adanya cuaca ekstrem terutama curah hujan yang sangat tinggi. Resapan air oleh pori batuan berkontribusi besar dalam menyebabkan timbulnya ketidaksetimbangan tanah lereng karena merupakan penyebab utama penambahan massa lereng dan penurunan gaya kohesi tanah.

Pada penelitian ini pengukuran geolistrik dilakukan menggunakan konfigurasi wenner untuk mendapatkan penampang 2D bawah permukaan. Metode geolistrik merupakan metode geofisika yang dapat menggambarkan struktur resistivitas bawah permukaan dan telah digunakan secara luas untuk berbagai aplikasi, seperti pendeteksian jalur pipa (Bulkis, 2008) maupun pada aplikasi pertambangan (Kusnahadi, 2012), dan lain sebagainya. Keunikan struktur geologi dan geomorfologi Jawa Barat menyebabkan potensi longsor terbesar berdasarkan Ludman (1982) adalah oleh curah hujan yang tinggi. Keberadaan kandungan air yang tinggi pada bidang longsor mengakibatkan kontras resistivitas yang cukup tinggi, sehingga metode geolistrik efektif digunakan dalam penyelidikan longsor tipe tersebut. Lokasi penelitian difokuskan pada dua daerah longsor pada cekungan Bandung utara yaitu Legok Hayam dan Cimenyan. Pada daerah Legok Hayam longsor telah terjadi, sementara daerah Cimenyan adalah daerah yang diperkirakan rawan longsor. Pengukuran di kedua area diharapkan dapat memberikan gambaran sebelum dan sesudah longsor di sekitar Bandung utara.

\section{Metode Penelitian}

Pada penelitian ini, akuisisi data geolistrik dilakukan pada lintasan paralel dalam rangka memenuhi kriteria untuk membentuk model 3D dari serial sectioning data 2D. Metode tahanan jenis adalah salah satu metode geofisika yang memanfaatkan sifat kelistrikan material bumi. Metoda ini menginjeksikan arus listrik searah ke dalam bumi melalui elektroda arus, selanjutnya distribusi medan potensialnya diukur dengan elektroda potensial yang diset menggunakan konfigurasi tertentu (Telford dkk, 1990). Hasil pengukuran berupa resistivitas semu 2D selanjutnya diolah untuk mendapatkan model 3D dari serial sectioning. (Susanto dkk, 2012, Wilantara dkk, 2013)Pada penelitian ini, rekonstruksi 3D dilakukan menggunakan algoritma interpolasi three linear, yang merupakan cara sederhana untuk menghitung interpolasi antar titiktitik penghubung dalam koordinat tiga dimensi. Hasil interpolasi menunjukkan adanya anomali konduktif yang merupakan objek pengukuran dan lokasinya (Susanto dkk, 2012). Metode ini juga dapat diterapkan untuk menghitung volum benda konduktif. 


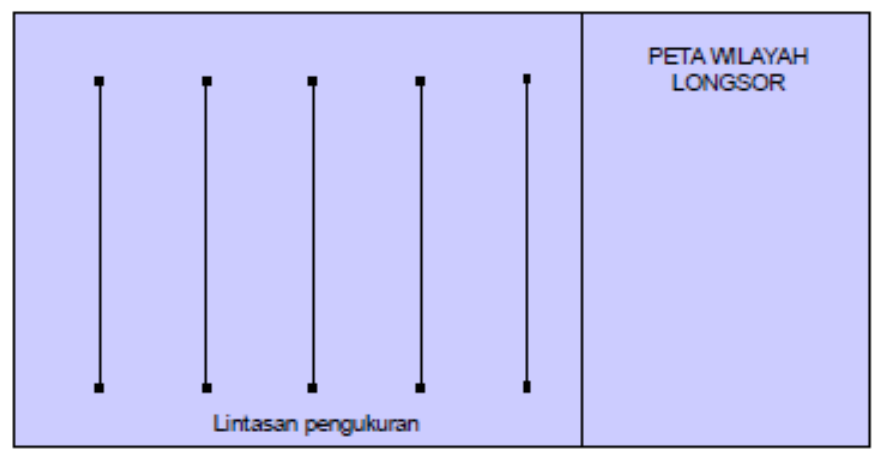

Gambar 1. Skema pengukuran paralel acquisition

Data pengukuran serial sectioning secara 2D selanjutnya diolah untuk menghasilkan citra resistivitas 3D. Secara umum langkah-langkah untuk memperoleh pencitraan resistivitas 3D adalah sebagai berikut: (Wilantara dkk,2013)

1. Melakukan proses griding data geolistrik 2D beserta data topografi

2. Melakukan penempatan penampang grid pada matriks array 3D (Gambar 2)

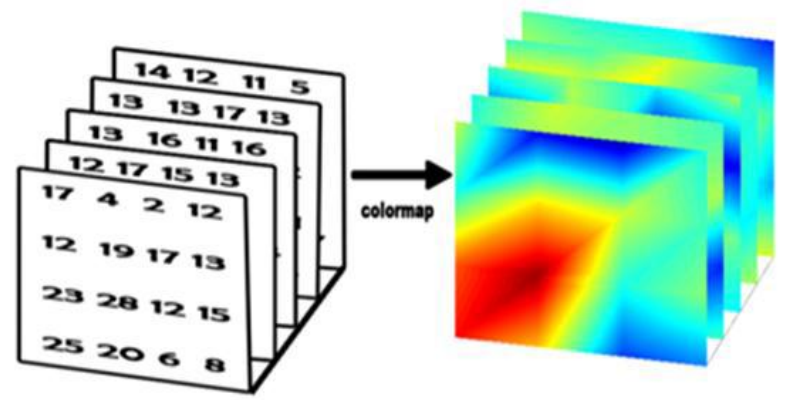

Gambar 2. Penempatan penampang grid pada matriks array 3D (Wilantara dkk, 2013)

3. Melakukan interpolasi three linear untuk mengisi nilai-nilai kosong diantara penampang grid yang berbeda (Gambar 3)

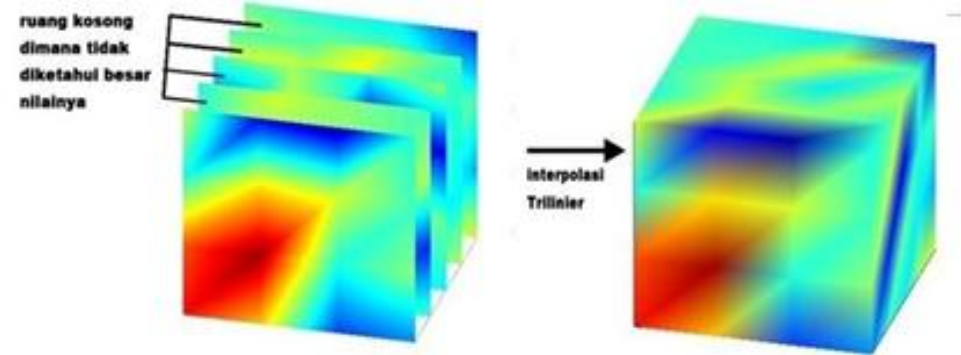

Gambar 3. Pengisian ruang kosong di antara penampang grid menggunakan interpolasi three linear (Wilantara dkk, 2013)

4. Melakukan proses isosurfacing untuk memperoleh nilai anomali konduktif yang berbeda dengan nilai konduktivitas background. (Gambar 4) 

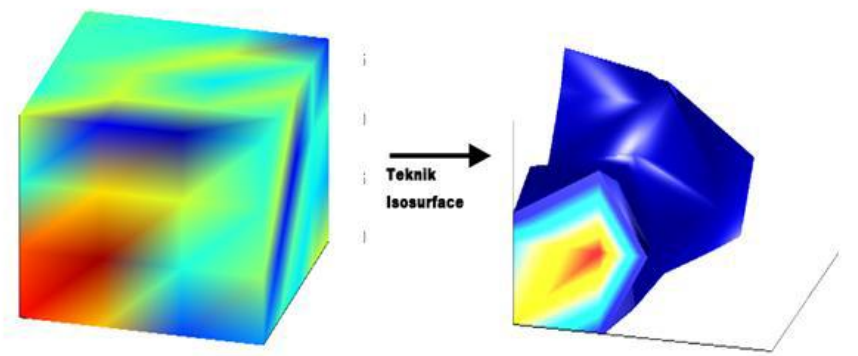

Gambar 4. Proses isosurfacing untuk mendapatkan nilai anomali konduktif yang merupakan target pengukuran (Wilantara dkk, 2013)

Hasil dari proses isosurfacing akan ditinjau sebagai anomali konduktif yang selanjutnya akan diinterpretasi untuk mengetahui penyebab longsor.

\section{Hasil dan Pembahasan}

Pola penampang resistivitas 2D lintasan 1 Legok Hayam sebagaimana ditunjukkan pada Gambar 5 memperlihatkan adanya lapisan yang memiliki nilai resistivitas pada kisaran puluhan Ohmmeter dan berada di atas zona dengan resistivitas rendah pada kisaran di bawah 10 Ohmmeter. Nilai-nilai resistivitas ini mengindikasikan suatu struktur 2D dua lapis, dengan lapisan resistivitas tinggi dapat diasumsikan sebagai lapisan penutup yang memungkinkan terjadinya infiltrasi air. Sementara lapisan bawah dengan nilai resistivitas rendah merupakan zona dengan saturasi air tinggi yang berkontribusi pada penambahan massa lereng. Berdasarkan Ludman (1982), keberadaan zona tersaturasi air yang menambah massa lereng merupakan pemicu terjadinya pergerakan tanah. Dengan demikian penampang 2D pada lintasan pertama mengindikasikan adanya pemicu longsor yang cukup signifikan.

Gambar 6 dan 7 memperlihatkan penampang resistivitas 2D untuk lintasan 2 dan 3. Pada Gambar 6, lintasan 2 memiliki nilai resistivitas yang relatif berada pada kisaran yang sama (puluhan Ohm.meter), dengan sedikit anomali resistivitas rendah dan tinggi di sekitar bagian tengah lintasan. Keberadaan nilai resistivitas yang berada pada kisaran relatif sama dengan nilai sekitar puluhan Ohm.meter menggambarkan suatu struktur yang relatif homogen dan terindikasi mengalami kejenuhan/saturasi air. Adanya nilai resistivitas sangat rendah pada orde di bawah 10 Ohm.meter menunjukkan timbulnya rembesan air di sekitar lintasan.

Adanya lapisan dengan nilai resistivitas yang relatif sangat tinggi (orde ratusan Ohm.meter) pada lintasan ketiga (Gambar 7) memperlihatkan struktur dua lapis dengan lapisan atas relatif sulit untuk menyerap air sementara lapisan bawah memiliki profil resistivitas yang mirip dengan lintasan kedua. Lapisan non permeable di atas lapisan permeable yang mulai tersaturasi air menunjukkan dimulainya proses penambahan massa lereng. 


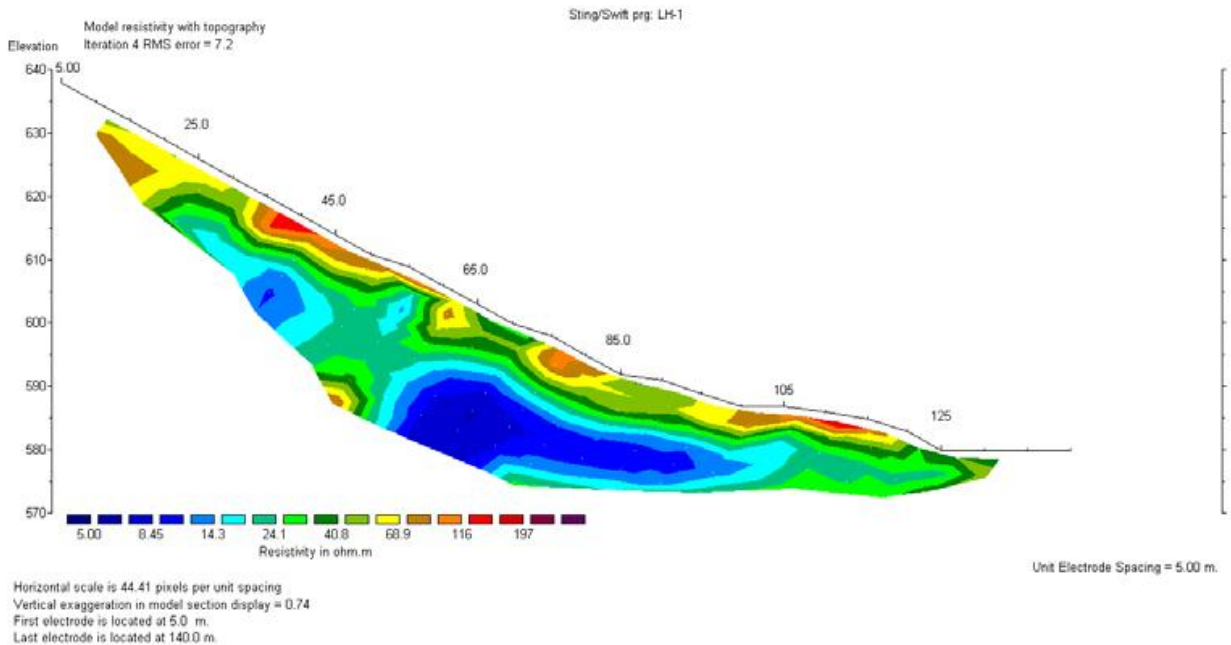

Gambar 5. Hasil Pengukuran Lintasan 1 daerah Legok Hayam

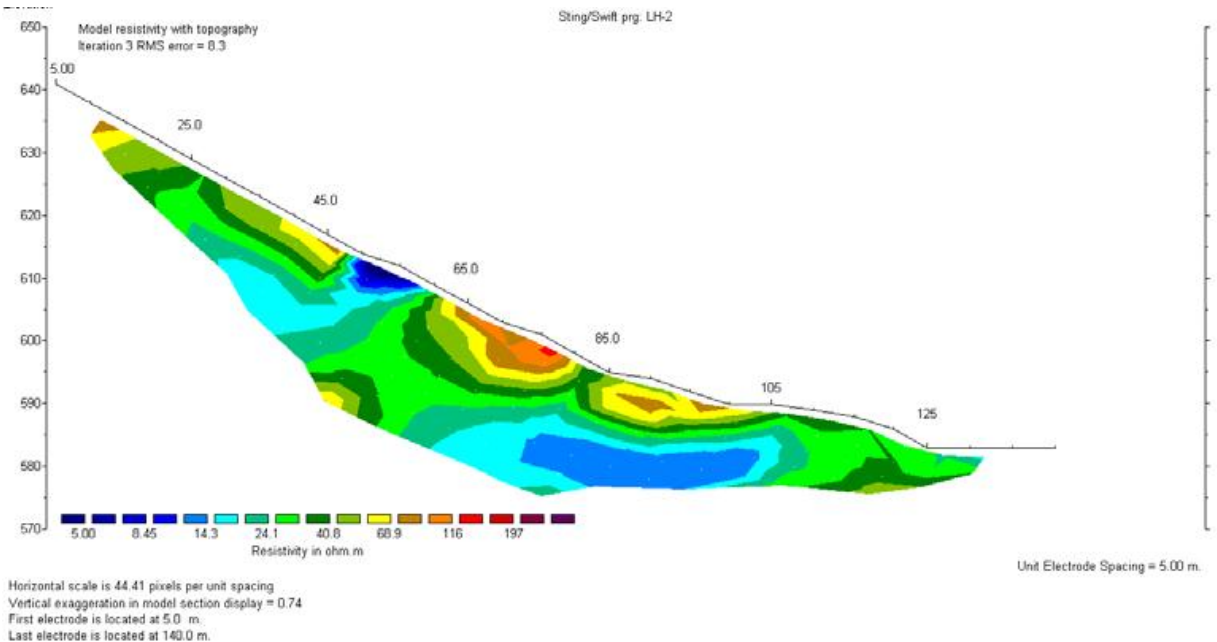

Gambar 6. Hasil Pengukuran Lintasan 2 daerah Legok Hayam

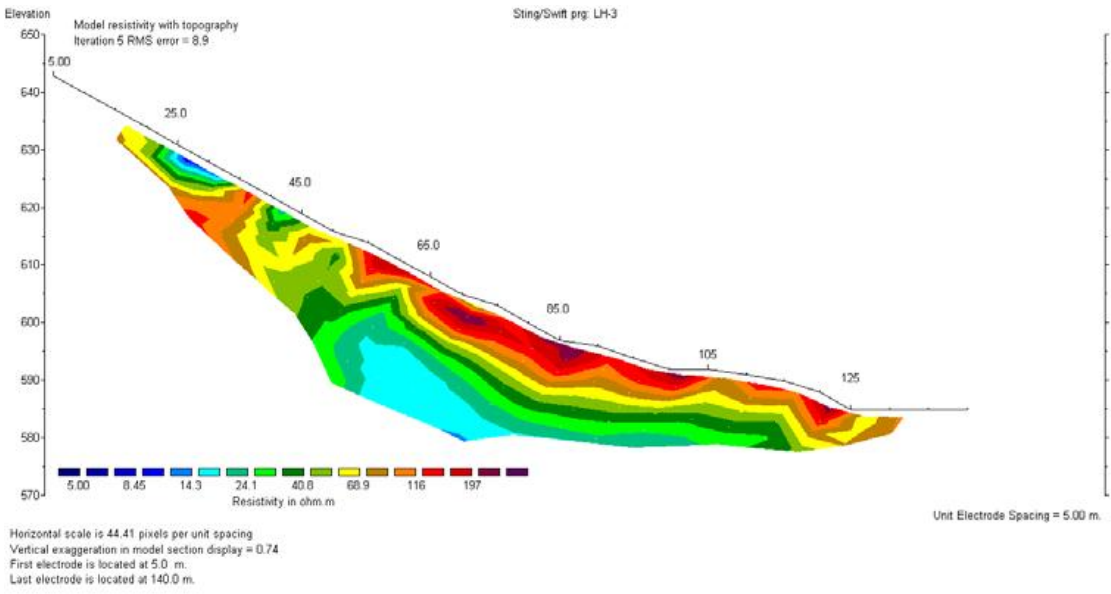

Gambar 7. Hasil Pengukuran Lintasan 3 daerah Legok Hayam 
Hasil citra 3D menggunakan proses serial sectioning, interpolasi three linear dan isosurfacing pada area penelitian Legok Hayam ditunjukkan pada Gambar 8. Citra 3D menunjukkan adanya area tersaturasi yang meluas pada seluruh area pengukuran. Penelitian daerah Legok Hayam dilakukan pada area dimana telah terjadi longsor, sehingga profil Legok Hayam menggambarkan kondisi resistivitas bawah permukaan pasca terjadinya longsor. Profil pasca longsor di Legok Hayam sebagaimana ditunjukkan Gambar 8 mengindikasikan terjadinya saturasi air diseluruh wilayah pengukuran yang berkontribusi besar pada keruntuhan lereng di daerah pengukuran.
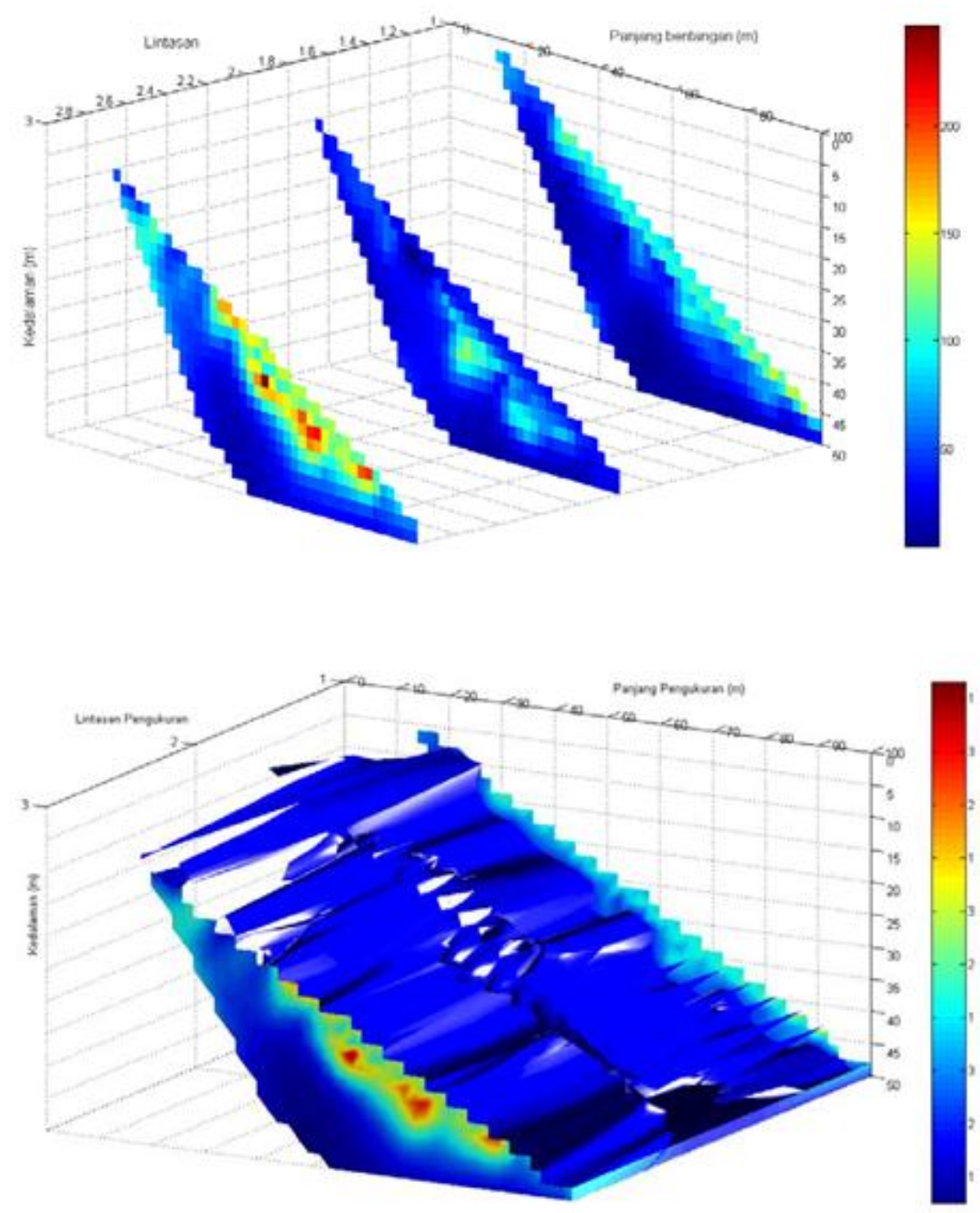

Gambar 8. Rekonstruksi citra 3D lintasan pengukuran daerah Legok Hayam

Selanjutnya pengukuran dilakukan pada daerah Cimenyan, dimana longsor belum terjadi namun diperkirakan merupakan lokasi dengan tingkat kerawanan tinggi berdasarkan bentuk topografi dan litologi daerah tersebut. Pada daerah Cimenyan pengukuran dilakukan pada empat lintasan sejajar. 
Profil resistivitas keempat lintasan tersebut diperlihatkan pada Gambar 9 - 12. Secara umum profil resistivitas keempat lintasan tersebut memperlihatkan ciri yang sama, yaitu adanya indikasi daerah struktur homogen dengan suatu anomali konduktif dengan nilai resistivitas lebih rendah dibandingkan nilai resistivitas latar belakangnya. Struktur resistivitas relatif homogen dengan nilai resistivitas tinggi mengindikasikan lapisan kedap air, sementara keberadaan anomali konduktif dengan nilai resistivitas rendah memperlihatkan adanya resapan terobosan yang mulai mengisi pori batuan bawah lintasan. Keberadaan terobosan resapan air mengindikasikan mulai adanya proses penambahan massa lereng, sehingga dengan ditunjang kondisi topografi dan litologi daerah sekitar maka tingkat kerawanan longsor di sekitar area pengukuran cukup tinggi.

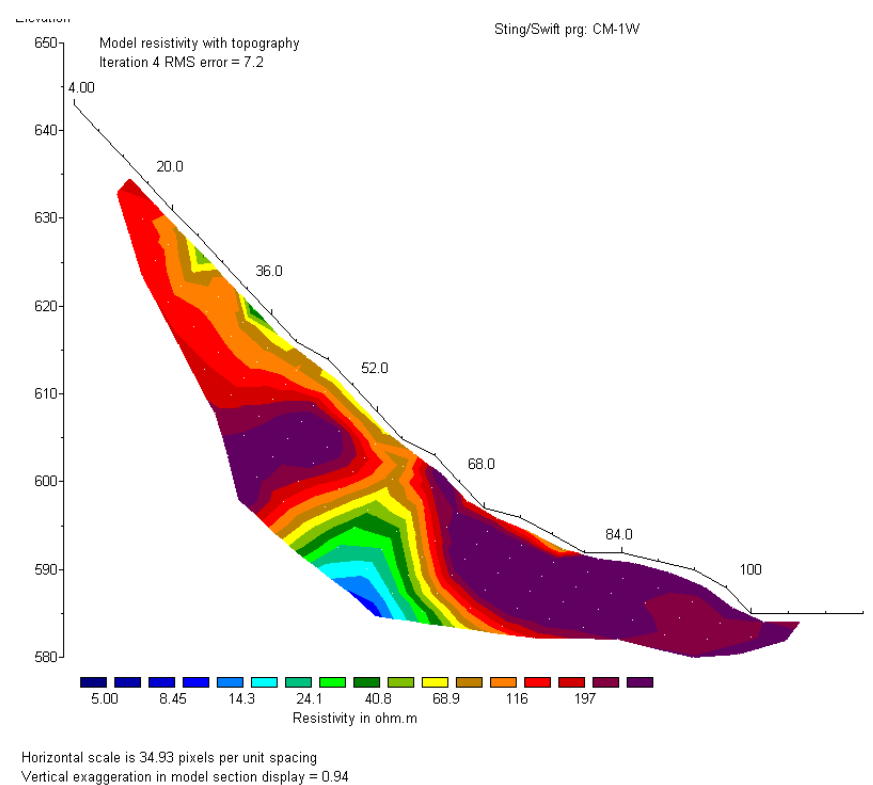

Unit Electrode Spacing $=4.00 \mathrm{~m}$

Horizontal scale is 34.93 pixels per unit spacing

Gambar 9. Hasil pengukuran lintasan 1 daerah Cimenyan

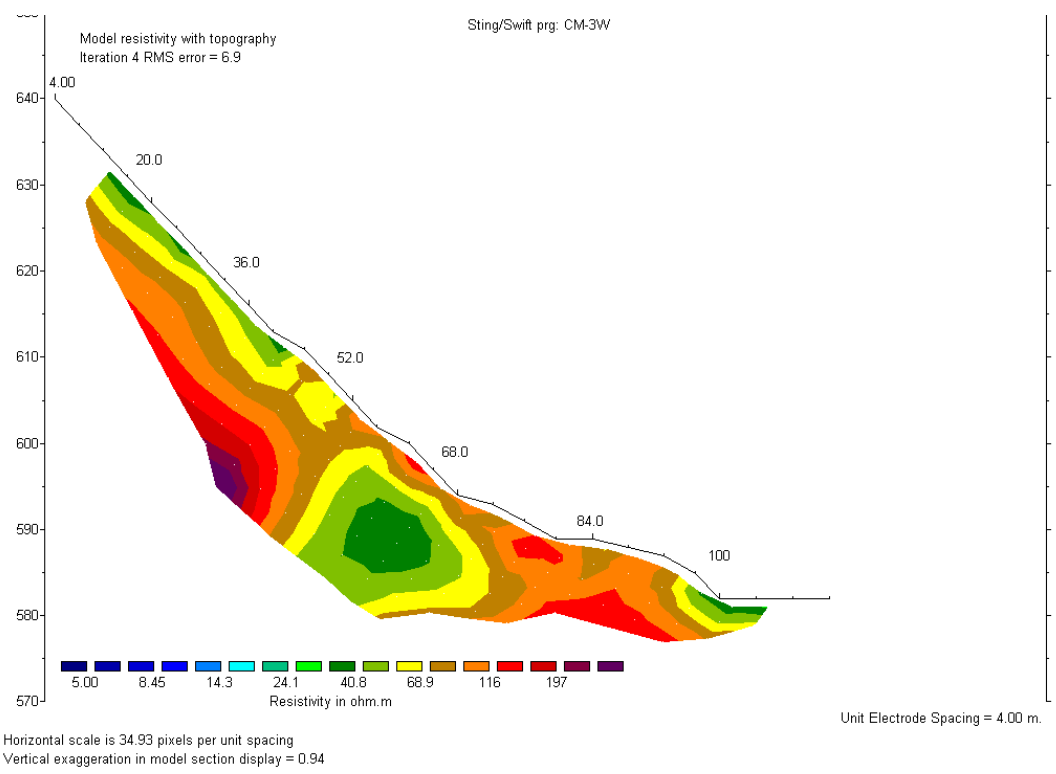

Gambar 10. Hasil pengukuran lintasan 2 daerah Cimenyan 


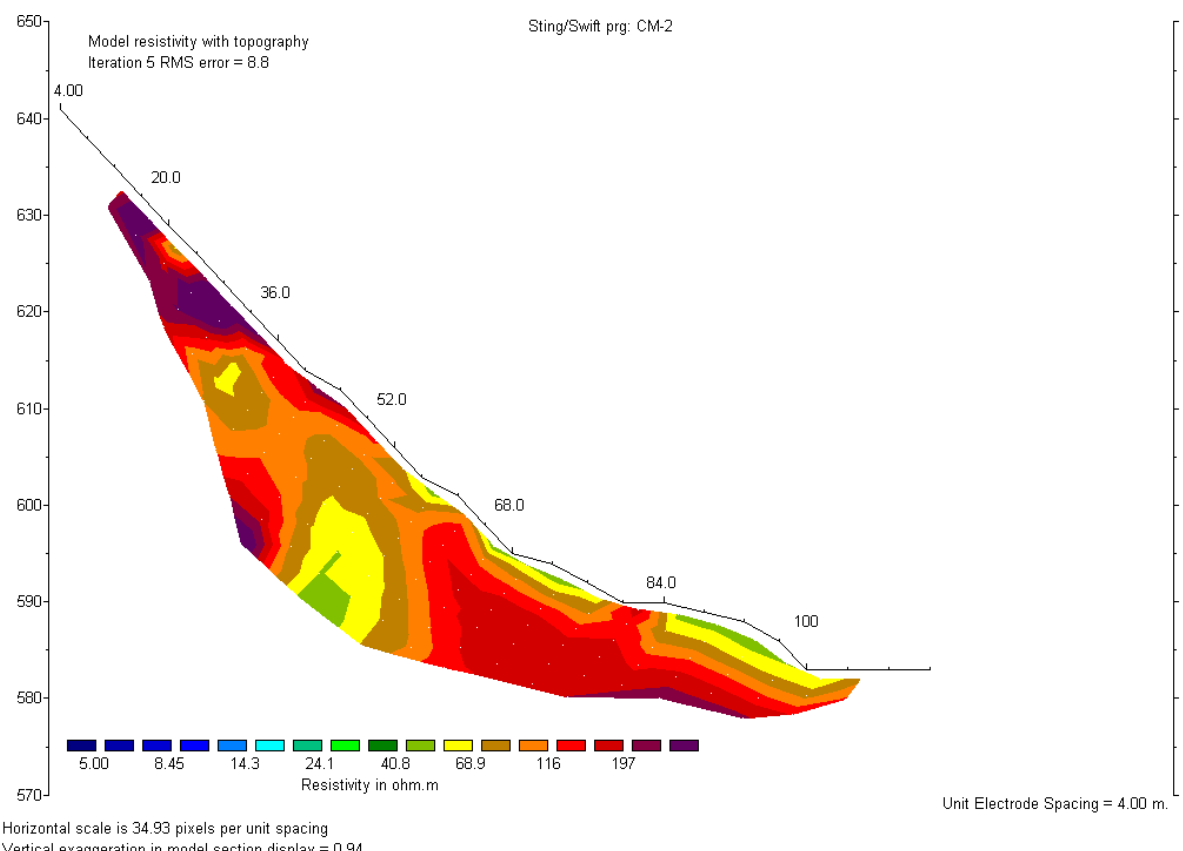

Horizontal scale is 34.93 pixels per unit spacing
Vertical exaggeration in model section display $=0.94$

Gambar 11. Hasil pengukuran lintasan 3 daerah Cimenyan

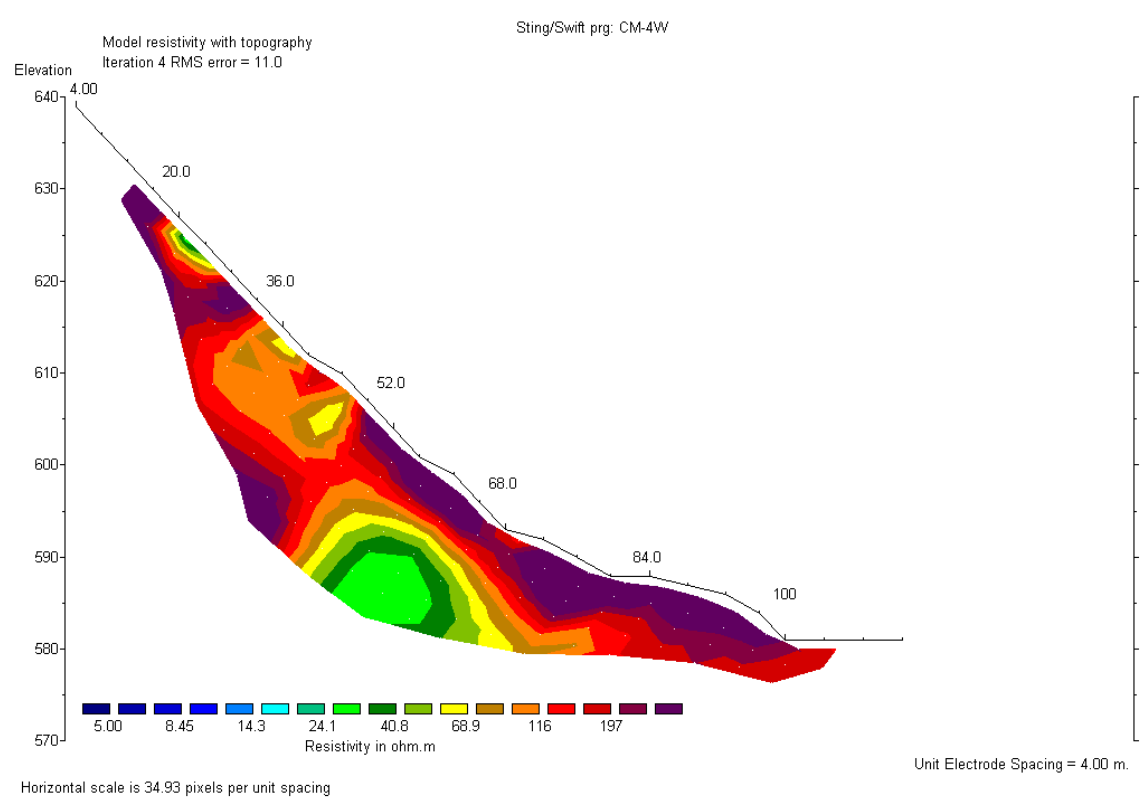

Horizontal scale is 34.93 pixels per unit spacing

Gambar 12. Hasil pengukuran lintasan 4 daerah Cimenyan

Rekonstruksi citra 3D dari keempat lintasan Cimenyan diperlihatkan pada Gambar 13. Adanya resapan secara terobosan sebagaimana diduga pada profil 2D per lintasan dikonfirmasi pada citra 3D. Hasil-hasil ini memperlihatkan tingkat kerawanan longsor yang cukup tinggi pada daerah Cimenyan. 

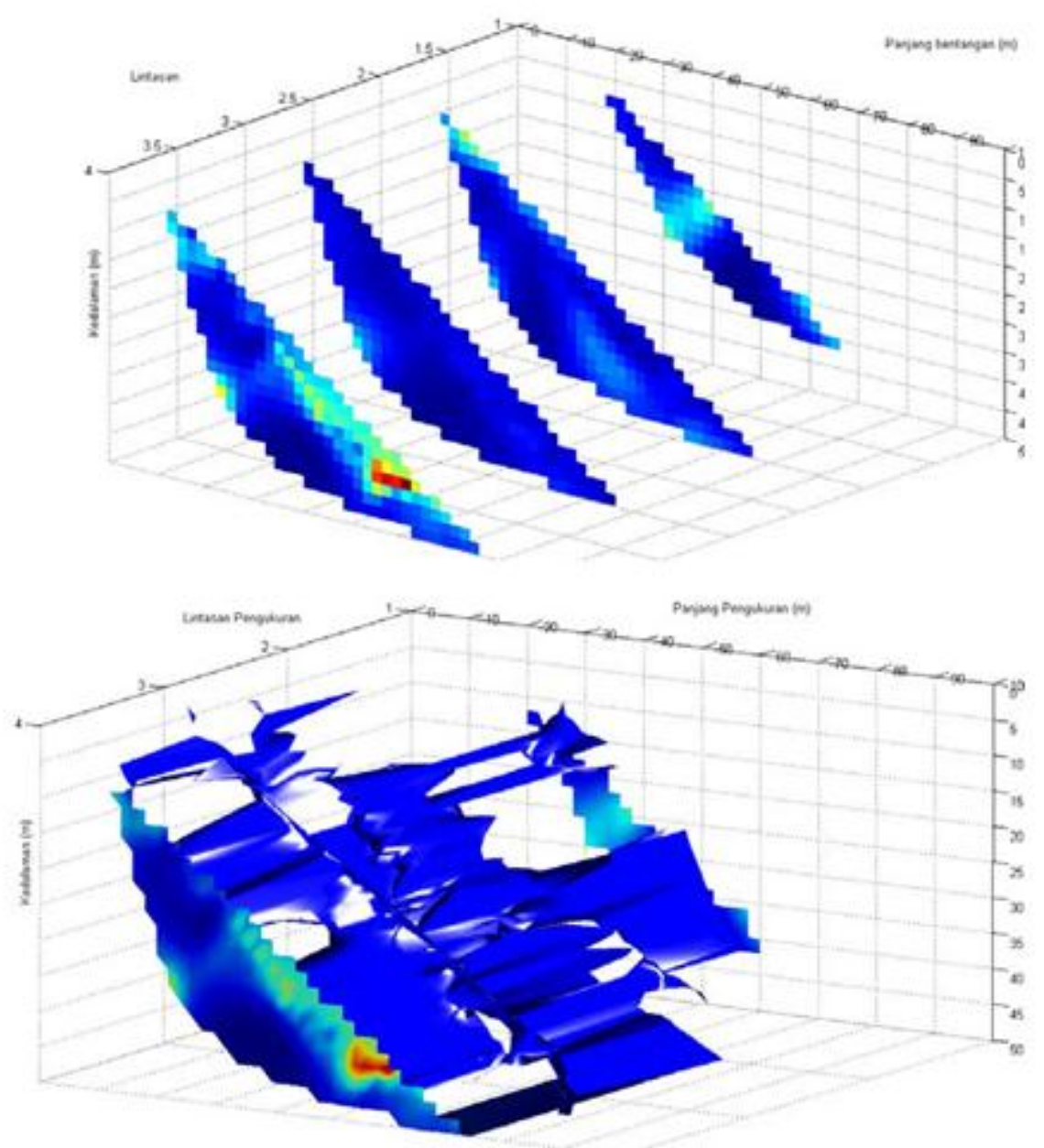

Gambar 13. Citra rekonstruksi 3D resistivitas daerah Cimenyan

\section{Kesimpulan}

Pengukuran resistivitas pada daerah terdampak longsor Legok Hayam dan rawan longsor Cimenyan di daerah Bandung utara telah dilakukan. Secara umum daerah terdampak longsor Legok Hayam memiliki profil resistivitas berbentuk dua lapis dengan profil lapisan atas berupa lapisan semi permeable dengan kisaran resistivitas puluhan Ohm.meter, sementara lapisan bawah memiliki profil resistivitas di bawah $10 \mathrm{Ohm}$.meter. Struktur resistivitas dua lapis pada daerah Legok Hayam mengindikasikan adanya longsoran pada bidang gelincir antar kedua lapisan. Sementara daerah Cimenyan memiliki profil resistivitas homogen yang memiliki anomali konduktif yang relatif tinggi. Keberadaan anomali konduktif mengindikasikan adanya terobosan resapan yang sedang berproses menambah massa lereng sehingga berpotensi terjadi kelongsoran.

\section{Ucapan terima kasih}

Penelitian ini didanai oleh Direktorat Jenderal Pendidikan Tinggi (DIKTI) dengan Program Penelitian Unggulan Perguruan Tinggi 2013. Penelitian ini juga disupport oleh Laboratorium GeNRe dan Laboratorium TCG, Universitas Padjadjaran. 


\section{Daftar Pustaka}

1. Ludman, A., and Coch, N.K., 1982, Physical Geology, Mc Graw-Hill

2. Bulkis, 2008. Aplikasi Metode Geolistrik Tahanan Jenis Konfigurasi WennerSchlumberger Untuk Survey Pipa Bawah Permukaan. Aplikasi Metode Geolistrik Teknologi Elektro . Vol. 7 No. 2 Juli - Desember 2008.

3. Telford, W. M., Geldart, L. P., \& Sheriff R. E. 1990. Applied Geophysics (Second edition). Cambridge University Press, New York.

1. Susanto, Kusnahadi dkk, 2012. Serial Sectioning 3D Data Induce Polarization (IP) Untuk Identifikasi Host Rock Daerah Tambang Logam. Prosiding Seminar Nasional \& Pertemuan Ilmiah Tahunan Himpunan Geofisika Indonesia (PIT-HAGI 34), Palembang.

2. Wilantara, G., Wijatmoko, B., Susanto, K, 2013. Rekonstruksi 3D Data Resistivitas Dengan Topografi Untuk Mengestimasi Volume Batuan. Proceeding Seminar Nasional Diponegoro Physics $1^{\text {st }}$ Conference, Semarang. 